\title{
ASSESSMENT HASIL BELAJAR SAINS MAHASISWA PADA MATA KULIAH ILMU ALAMIAH DASAR DI MASA PANDEMI
}

\author{
Muhammad Syazali", Lalu Wira Zain Amrullah, Nurwahidah \\ Program Studi PGSD, FKIP Universitas Mataram, Indonesia \\ *Corresponding Author: m.syazali@unram.ac.id
}

\author{
Article History \\ Received : February $22^{\text {th }}, 2021$ \\ Revised : March $13^{\text {th }}, 2021$ \\ Accepted : March 19 ${ }^{\text {th }}, 2021$ \\ Published : May $05^{\text {th }}, 2021$
}

\begin{abstract}
Abstrak: Aspek yang menjadi kekhawatiran pada bidang pendidikan dimasa pandemi adalah hasil belajar melalui pelaksanaan pembelajaran daring akibat tidak memungkinkannya pembelajaran secara tatap muka. Tujuan penelitian ini adalah melakukan assessment terhadap hasil belajar mahasiswa pada mata kuliah Ilmu Alamiah Dasar (IAD). Penelitian dilakukan pada mahasiswa Program Studi (Prodi) Pendidikan Guru Sekolah Dasar (PGSD), FKIP Universitas Mataram semester gasal tahun akademik 2020/2021. Sampel penelitian terdiri atas 97 mahasiswa yang dipilih secara random. Data hasil belajar adalah nilai akhir aspek kognitif yang diolah dari tiga jenis ujian (U) yaitu yaitu U1, U2, dan U3. U1 mencakup kuis, penugasan, dan lain-lain selama perkuliahan. U2 dan U3 diambil dari hasil ujian tengah semester (UTS) dan ujian akhir semester (UAS). Hasil belajar ditentukan dengan mengukur derajat penguasaan dan dinterpretasi ke dalam 5 kategori yaitu sangat baik, baik, cukup, kurang, dan sangat kurang. Analisis data menggunakan statistik deskriptif. Hasil analisis menunjukkan bahwa rata-rata hasil belajar mahasiswa adalah 75.83 dengan kategori baik. Mahasiswa laki-laki memiliki derajat penguasaan yang lebih tinggi dibandingkan dengan mahasiswa perempuan. Berdasarkan proporsinya, derajat penguasaan dengan kategori sangat baik dan baik memiliki persentase sebesar 93.81\%. Sisanya kategori cukup $4.12 \%$ dan kategori sangat kurang 2.06\%. Di masa pandemi Covid-19 ini, mahasiswa mampu menguasai tujuan-tujuan pembelajaran dengan baik. Capaian ini perlu dipertahankan dan ditingkatkan melalui implementasi pembelajaran yang dapat mengoptimalkan potensi mahasiswa.
\end{abstract}

Kata kunci: derajat penguasaan, hasil belajar, pembelajaran daring.

\section{PENDAHULUAN}

Pembelajaran secara daring yang "terpaksa" dilakukan pada masa pandemi Covid19 menimbulkan efek negatif. Beberapa di antaranya mahasiswa merasa bosan belajar secara daring (Indrawati, 2020), pemahaman mahasiswa terhadp materi tidak optimal dan pembelajaran tidak efektif akibat pemberian tugas yang berlebihan (Widiyono, 2020), dan mahasiswa memberikan persepsi yang cenderung negatif terhadap pembelajaran daring, baik dari aspek materi, interaksi maupun lingkungan belajar (Zamista et al., 2020). Efek negatif tersebut muncul karena adanya kendala-kendala dalam pelaksanaan pembelajaran secara daring. Kendala-kendala tersebut di antaranya sinyal atau jaringan yang tidak stabil, perangkat PC atau HP yang tidak mendukung, kerumitan aplikasi dan rendahnya literasi ICT, keterbatasan biaya untuk membeli kuota internet, lingkungan tidak memadai untuk perkuliahan daring, dan penyampaian materi tidak optimal (Indrawati, 2020; Legowo, 2020; Nainggolan et al., 2020).

Kendala-kendala pada implementasi pembejaran secara daring juga terjadi di Program Studi (Prodi) Pendidikan Guru Sekolah Dasar (PGSD), FKIP Universitas Mataram. Rahmatih \& Fauzi (2020) menemukan bahwa proporsi mahasiswa yang merespon negatif terhadap kemudahan interaksi horizontal dengan sesama mahasiswa sebesar $67.1 \%$. Faktor ini berdampak pada kecilnya persentase mahasiswa yang dapat melakukan penyelesaian terhadap permasalahan secara berkelompok. Proporsi mahasiswa yang memberikan respon negatif terhadap interaksi dengan dosen lebih tinggi yaitu $71 \%$. Faktor ini menyebabkan rendahnya rasa nyaman mahasiswa dalam berpendapat dan mencurahkan buah pikirannya selama pembelajaran. Kendala 
lain yang ditemukan adalah rendahnya motivasi mahasiswa dalam pembelajaran dan menguasai tujuan-tujuan pembelajaran. Mahasiswa merasa lebih nyaman difasilitasi melalui pembelajaran tatap muka. Faktor ini sendiri menyebabkan rendahnya penguasaan mahasiswa terhadap materi yang diberikan.

Hasil penelitian lain menunjukkan bahwa mahasiswa PGSD FKIP Universitas Mataram memiliki kesiapan belajar daring yang kurang (Widodo et al., 2020). Kendala lain yang ditemukan adalah literasi ICT yang masih rendah, biaya untuk membeli kuota yang terbatas dan koneksi internet tidak stabil, dan banyak mahasiswa berharap supaya pembelajaran tatap muka segera kembali dilaksanakan. Dari aspek persiapan untuk belajar secara daring, hanya $5.10 \%$ mahasiswa yang selalu dalam keadaan siap. Sisanya sebanyak $17.90 \%$ menjawab sering dan yang predominan adalah mahasiswa melakukan persiapan kadang-kadang $46.20 \%$ serta tidak pernah sama sekali sebanyak $30.80 \%$. Dari aspek kemampuan dalam mengikuti pembelajaran daring, hanya $18.40 \%$ yang bisa mengikuti dengan baik, sisanya sebanyak 81.60\% tidak bisa mengikuti dengan baik. Adapun dari aspek penguasaan terhadap materi yang dibelajarkan, hanya $13.40 \%$ yang merasa mampu menyerap pelajaran dengan baik, sedangkan sebanyak $86.60 \%$ lainnya merespon negatif.

Berbagai fakta terhadap kelemahan pembelajaran daring menimbulkan kekhawatiran terutama dampaknya terhadap hasil belajar mahasiswa. Pada penelitian ini, kami melakukan assessment terhadap hasil belajar sains mahasiswa PGSD FKIP Universitas Mataram yang memprogramkan mata kuliah IAD. Hasil belajar ditinjau dari nilai akhir (NA) yang menggambarkan derajat penguasaan mahasiswa terhadap pembelajaran IAD yang dilakukan selama satu semester. Hasil penelitian ini memberikan gambaran terkait kompetensi sains mahasiswa, dan memetakan posisi mereka terhadap sesama mahasiswa serta terhadap capaian pembelajaran mata kuliah di masa pandemi Covid-19. Gambaran dan pemetaan tersebut dapat dimanfaatkan sebagai acuan ilmiah untuk merancang rencana pelaksanaan semester yang lebih efektif agar hasil pembelajaran sains mahasiswa menjadi lebih baik.

\section{METODE}

Penelitian dilakukan pada mahasiswa PGSD FKIP Universitas Mataram tahun akademik 2020/2021 yang memprogramkan mata kuliah IAD. Sampel terdiri dari 97 mahasiswa yang dipilih secara random. Selama perkuliahan mereka mendapat fasilitas pembelajaran secara daring. Pembelajaran daring dilakukan melalui Sistem Pembelajaran Daring Universitas Mataram (SPADA Unram), dan Google Meet. Di SPADA Unram dibuatkan akun khusus untuk pembelajaran IAD yang dapat diakses selama 24 jam, kecuali beberapa hal. Akun mata kuliah IAD dilengkapi dengan berbagai menu untuk memfasilitasi mahasiswa dalam belajar. Beberapa menu tersebut di antaranya folder bahan ajar, menu submit tugas, Quiz, Ujian Tengah Semester (UTS), dan Ujian Akhir Semester (UAS). Google Meet hanya digunakan pada saat jadwal pembelajaran yang dilaksanakan selama 1 kali dalam seminggu. Selain secara daring, terdapat juga topik yang pembelajarannya dilakukan secara luring. Topik tersebut adalah "Interaksi antara Makhluk Hidup dan Lingkungannya", dan "Keanekaragaman Hayati". Pelaksanaan pembelajaran luring memanfaatkan lingkungan sekitar mahasiswa sebagai sumber belajar.

Data hasil belajar adalah Nilai Akhir (NA) yang diolah dari 3 ujian (U) yaitu U1, U2, dan U3. U1 merupakan rata-rata (mean) dari dari hasil kerja mahasiswa yang dilakukan secara individu dan kelompok. Hasil kerja individu terdiri atas lembar kerja, resume, daftar pertanyaan, dan quiz. Hasil kerja kelompok mencakup lembar hasil pengamatan, laporan, dan video. U2 merupakan hasil Ujian Tengah Semester (UTS), dan U3 merupakan hasil Ujian Akhir Semester (UAS). Untuk mendapatkan NA, dilakukan analisis Derajat Penguasaan (DP) yang memiliki rentang $0-100$ mengacu pada Pedoman Akademik Universitas Mataram (Tim Penyusun, 2019). Berdasarkan DP ditentukan grade dan kategori. Grade dikalsifikasikan menjadi 7 yaitu $\mathrm{A}, \mathrm{B}+, \mathrm{B}, \mathrm{C}+, \mathrm{C}, \mathrm{D}+, \mathrm{D}$, dan $\mathrm{E}$. Grade $A$ diinterpretasi menjadi kategori sangat baik (SB), B+ dan B kategori baik (B), C+ dan C kategori cukup (C), D+ dan D kategori kurang (K), dan E kategori sangat kurang (SK). Data 
hasil belajar kemudian dianalisis secara deskriptif dengan bantuan SPSS for windows versi 25 .

\section{HASIL DAN PEMBAHASAN}

\section{Rata-rata Derajat Penguasaan Sains}

Analisis secara deskriptif menunjukkan rata-rata derajat penguasaan mahasiswa pada mata kuliah IAD adalah 75.83 dengan interpretasi baik. Derajat penguasaan paling rendah adalah 23.00 dengan kategori sangat kurang, sedangkan derajat penguasaan tertinggi adalah 87.00 dengan kategori sangat baik. Rentang atau range menunjukkan nilai sebesar 64.00 dengan kategori cukup. Nilai tengah atau median sebesar 78.31 dengan kategori baik. Hasil analisis menggunakan statistik deskriptif lainnya dapat diamati pada Tabel 1 berikut ini. Adapun histogramnya disajikan pada Gambar 1.

Tabel 1. Ukuran pemusatan dan sebaran data hasil belajar mahasiswa.

\begin{tabular}{clccc}
\hline No & Statistik deskriptif & Derajat Penguasaan & Nilai & Kategori \\
\hline 1 & Mean & 75.83 & B+ & Baik \\
2 & Standar error mean & 1.04 & - & - \\
3 & Median & 78.31 & B+ & Baik \\
4 & Modus & 80.00 & A & Sangat Baik \\
5 & Standar deviasi & 10.19 & - & - \\
6 & Variansi & 103.94 & - & - \\
7 & Range & 64.00 & C+ & Cukup \\
8 & Minimum & 23.00 & E & Sangat Kurang \\
9 & Maksimum & 87.00 & A & Sangat Baik \\
10 & Persentil 25 & 73.27 & B+ & Baik \\
11 & Persentil 50 & 78.31 & B+ & Baik \\
12 & Persentil 75 & 80.86 & A & Sangat Baik \\
\hline
\end{tabular}

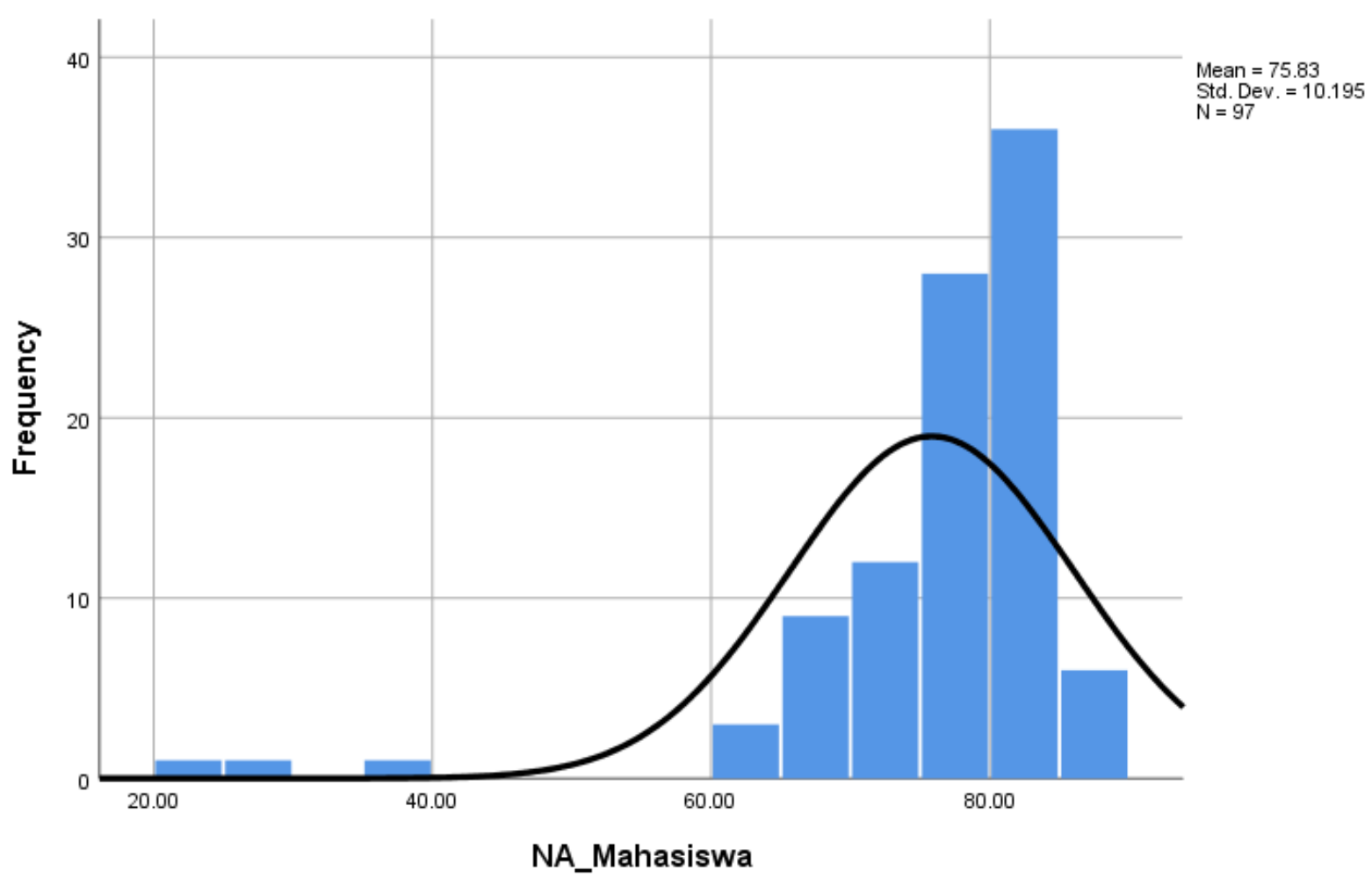

Gambar 1. Histogram data hasil belajar mahasiswa

Gambar 1 menunjukkan bahwa frekuensi dengan derajat penguasaan di bawah 60.00 lebih rendah dibandingkan dengan frekuensi derajat penguasaan di atasnya. Mulai dari 60.00 frekuensinya mengalami peningkatan sampai pada derajat penguasaan di atas 80.00 yang paling tinggi, dan frekuensinya menurun pada derajat penguasaan yang mendekati maksimum (derajat penguasaan paling tinggi). 
Berdasarkan jenis kelamin, rata-rata derajat penguasaan sains mahasiswa laki-laki lebih tinggi dibandingkan dengan rata-rata derajat penguasaan sains mahasiswa perempuan $(80.45$ > 75.3). Derajat penguasaan mahasiswa laki-laki memiliki kategori baik sekali, sedangkan derajat penguasaan mahasiswa perempuan memiliki kategori baik. Derajat

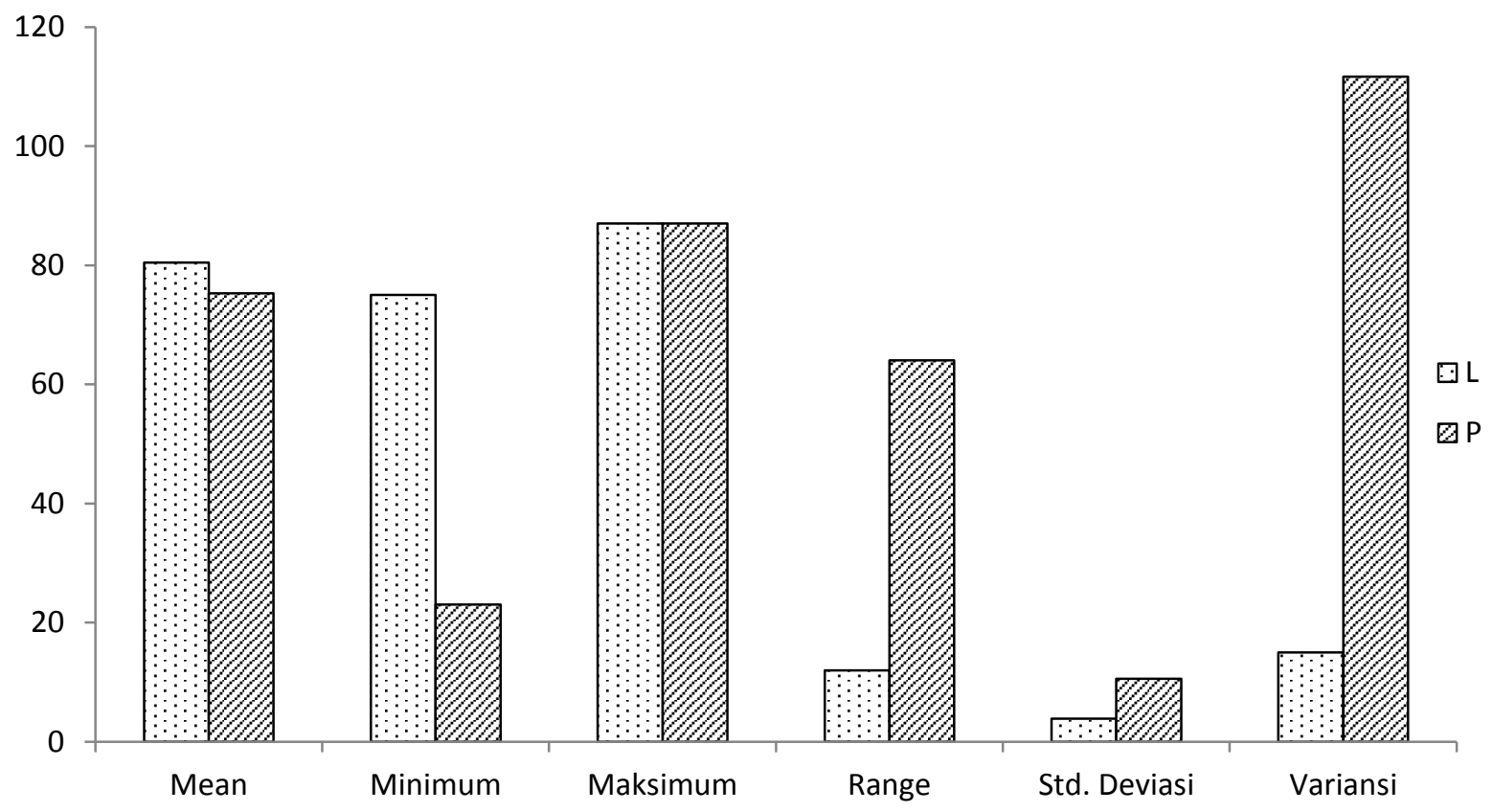

Gambar 2. Perbandingan derajat penguasaan mahasiswa laki-laki (L) dan perempuan (P)

\section{Proporsi Derajat Penguasaan Sains}

Berdasarkan kategorinya, proporsi terbesar dari derajat penguasaan sains mahasiswa pada mata kuliah IAD adalah kategori baik $(59.79 \%)$. Derajat penguasaan pada kategori ini

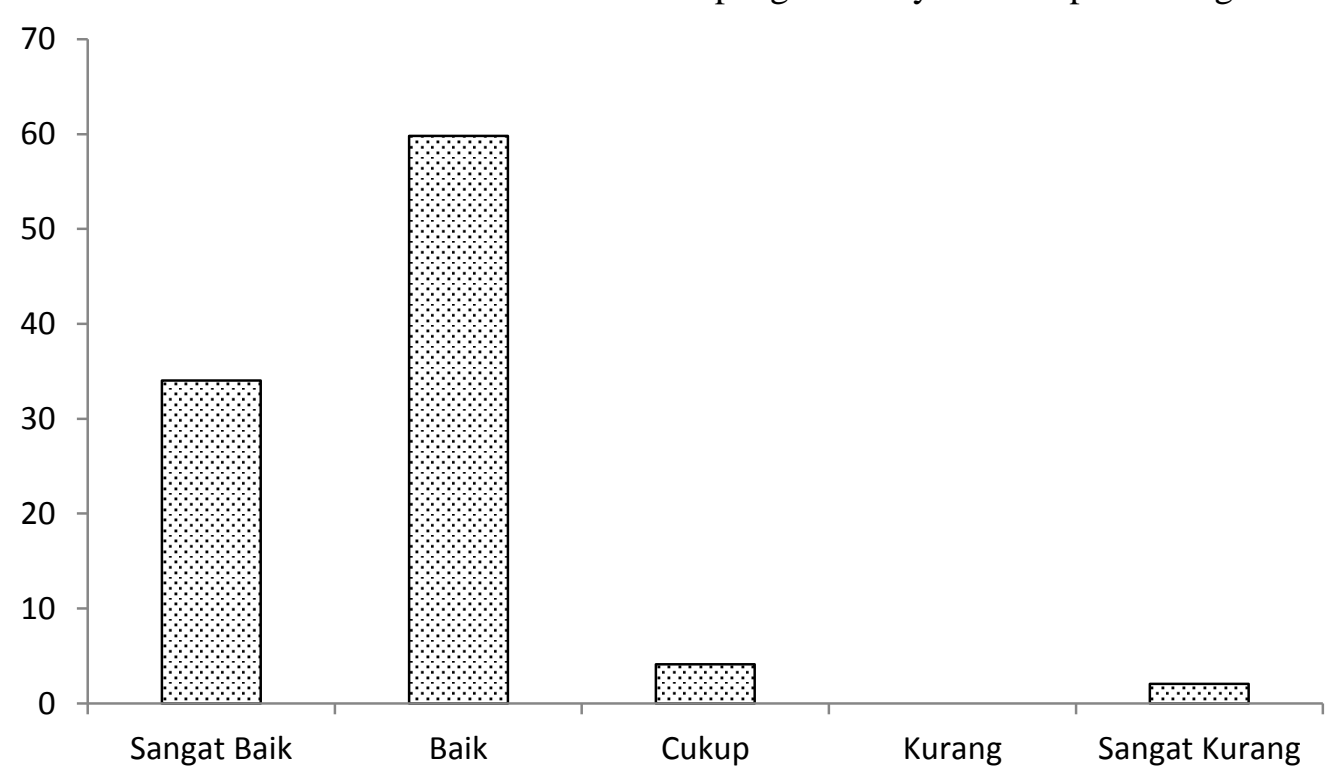

Gambar 3. Proporsi derajat penguasaan sains mahasiswa berkisar dari 65.00 sampai dengan 79.00. Kategori lain memiliki proporsi yang berkisar dari $2.06 \%$ dengan kategori sangat kurang sampai dengan $34.02 \%$ dengan kategori sangat baik (Gambar 3). Tidak ada mahasiswa yang derajat penguasaannya berada pada kategori kurang. penguasaan minimum mahasiswa laki-laki juga lebih tinggi dibandingkan dengan derajat penguasaan minimum mahasiswa perempuan. Walaupun derajat penguasaan kedua kelompok sama, namun range, standar deviasi dan variansi derajat penguasaan mahasiswa laki-laki lebih kecil dibandingkan dengan mahasiswa perempuan (Gambar 2). 
Berdasarkan jenis kelamin dan kategori, derajat penguasaan mahasiswa laki-laki berkisar dari 75.00 dengan kategori baik sampai dengan 87.00 dengan kategori sangat baik. Derajat penguasaan mahasiswa perempuan lebih bervariasi dengan derajat penguasaan berkisar dari 23.00 sampai dengan 87.00. Kategorinya juga lebih bervariasi yaitu sangat kurang, cukup, baik dan sangat baik (Gambar 4). Mahasiswa laki-laki memiliki proporsi deeajat penguasaan dengan kategori sangat baik yang lebih tinggi (60\%) dibandingakn dengan mahasiswa perempuan (31.03\%), namun proporsi mahasiswa perempuan untuk kategori baik lebih tinggi dibandingakan dengan mahasiswa laki-laki $(62.07 \%>40 \%)$.

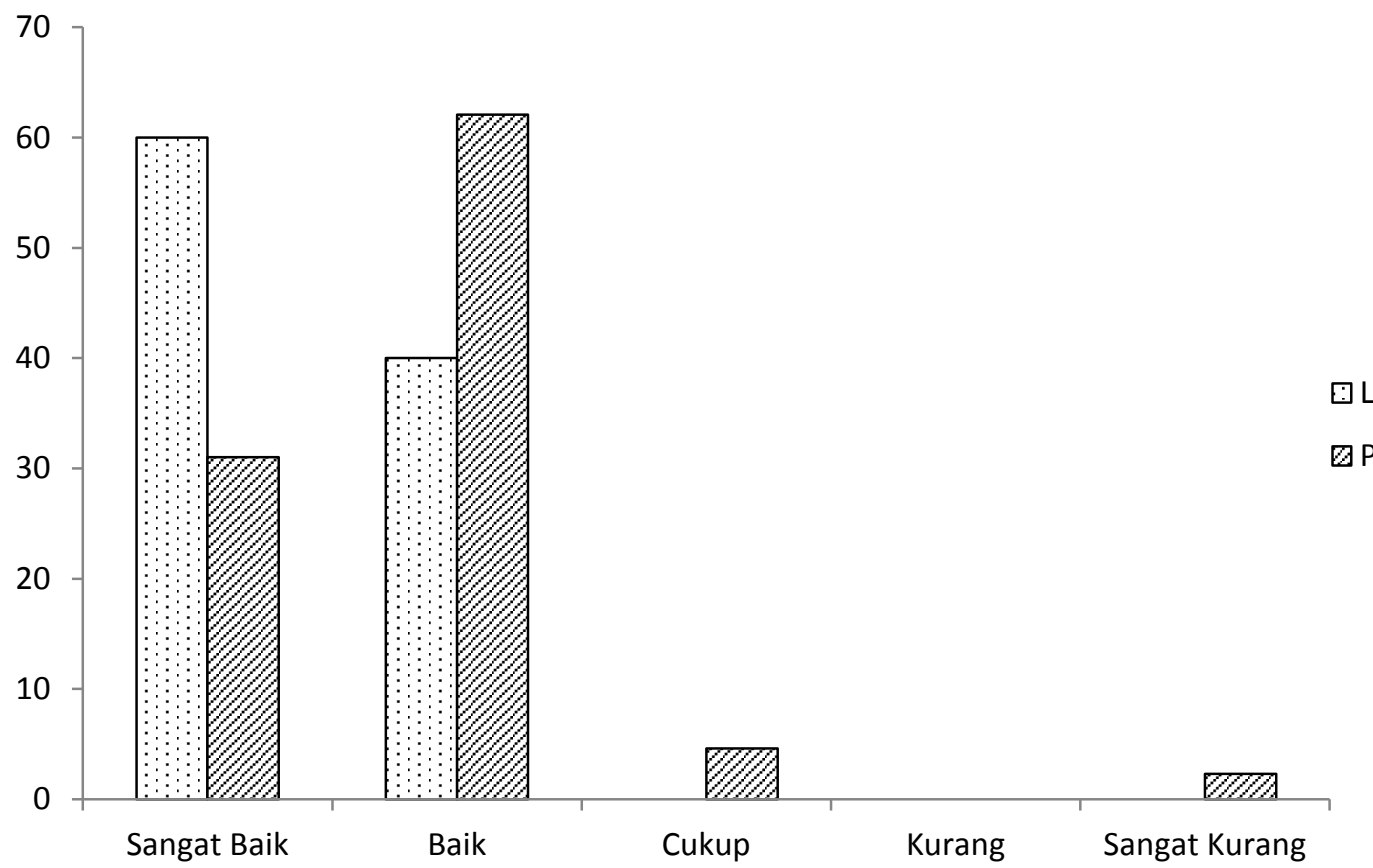

Gambar 4. Perbandingan proporsi derajat penguasaan sains mahasiswa L dan P

\section{Pembahasan}

Hasil belajar sains mahasiswa PGSD FKIP Universitas Mataram yang memprogramkan mata kuliah IAD pada masa pandemi Covid-19 berada pada kategori baik (Tabel 1). Hasil pembelajaran yang bagus melalui implementasi pembelajaran daring juga dilaporkan oleh peneliti lain. Sutriyani (2020) menemukan bahwa penerapan pembelajaran daring berpengaruh positif terhadap peningkatan hasil belajar mahasiswa PGSD Unisnu Jepara. Nilai tertinggi bahkan mencapai 94. Di Universitas Sarjanawiyata Tamansiswa, rata-rata hasil belajar mahasiswa PGSD berkisar dari 70.23 sampai dengan 92.23 (Trisniawati et al., 2020). Jika dilakukan interpretasi berdasarkan Pedoman Akademik Universitas Mataram (Tim Penyusun, 2019), maka hasil belajar mahasiswa tersebut berada pada kategori baik sampai dengan sangat baik. Apabila difasilitasi dengan pembelajaran yang tepat, hasil pembelajaran sains mahasiswa tetap bagus walaupun dimasa pandemi ini, dan bahkan dapat meningkatkan kemampuan HOTS mereka (Atmojo et al., 2020).
Jika mengacu pada hasil-hasil penelitian tersebut maka perubahan pendekatan pembelajaran dari luring menjadi daring tidak sepenuhnya berefek negatif terhadap hasil belajar mahasiswa.

Hasil belajar yang baik dimasa pandemi Covid-19 yang pembelajarannya harus dilakukan secara daring dan tidak dimungkinakan secara tatap muka menunjukkan bahwa mahasiswa mampu melakukan habituasi dengan baik. Walaupun terdapat berbagai kendala dari berbagai aspek (Rahmatih \& Fauzi, 2020; Widodo et al., 2020), namun mereka tetap bisa memanfaatkan segala potensi yang ada untuk bisa menguasai tujuan-tujuan pembelajaran. Hal ini dapat diamati dari bentuk histogram dari hasil analisis deskriptif data hasil belajar. Frekuensi derajat penguasaan terhadap sains di bawah 60.00 jauh lebih rendah dibandingkan dengan derajat pengetahuan di atasnya (Gambar 1). Selama pembelajaran di masa pandemi Covid-19 ini, sebenarnya hanya pembelajaran terjadwal yang mengalami perubahan mendadak yaitu dari tatap muka menjadi daring. Tatap muka pun sebenarnya tetap dilakukan hanya saja melalui video conference dengan memanfaatkan Google 
Meet. Pembelajaran lain seperti penyelesaian tugas-tugas kuliah hampir tidak mengalami perubahan, kecuali diskusi kelompok yang harus dilakukan secara daring.

Ditinjau dari jenis kelamin, hasil belajar mahasiswa laki-laki lebih bagus dibandingkan dengan mahasiswa perempuan. Rata-rata derajat penguasaan mahasiswa laki-laki berkategori sangat baik sedangkan rata-rata derajat penguasaan mahasiswa perempuan berkategori baik (Gambar 2). Hal ini menunjukkan bahwa daya habituasi mahasiswa laki-laki lebih bagus dibandingkan dengan daya habituasi mahasiswa perempuan terhadap penerapan pembelajaran daring. Daya habituasi penting bagi mahasiswa karena dapat membantunya dalam menyerap materi dari dosen dengan baik sesuai tujuan pembelajaran (Fanani \& Jainurakhma, 2020). Fakta bahwa hasil belajar mahasiswa laki-laki lebih baik dibandingkan dengan hasil belajar mahasiswa juga mengindikasikan bahwa fasilitas pembelajaran yang diberikan pada mata kuliah IAD di masa pandemi Covid-19 relatif lebih sesuai untuk mahasiswa laki-laki daripada mahasiswa perempuan. Fasilitas pembelajaran yang diberikan mencakup sistem pembelajaran daring (SPADA) milik Universitas Mataram dan platform video converence yaitu Google Meet dan Zoom.

Berdasarkan kategorinya, hasil belajar sains yang predominan adalah derajat penguasaan dengan kategori baik dan sangat baik, sisanya adalah kategori cukup dan sangat kurang dengan proporsi yang sangat kecil (Gambar 3). Tidak terdapat mahasiswa dengan derajat penguasaan berkategori kurang. Secara umum hasil belajar mahasiswa bagus, namun ini tidak berlaku pada $2.30 \%$ mahasiswa. Sebenarnya, hasil U1 mereka memiliki kategori baik sampai dengan sangat baik namun nilai U3 mereka kosong. Berdasarkan Pedoman Akademik Universitas Mataram (Tim Penyusun, 2019), nilai U3 menyumbang 50\% dari penentuan derajat penguasaan. Pada tiap proporsi berdasarkan kategori, terdapat proporsi mahasiswa laki-laki dan perempuan, kecuali pada kategori cukup dan sangat kurang (Gambar 4). Derajat penguasaan dengan kategori sangat baik dan baik predominan terhadap derajat penguasaan dengan kategori di bawahnya, baik pada mahasiswa laki-laki maupun mahasiswa perempuan. Data proporsi ini secara tersurat menunjukkan hasil belajar sains mahasiswa di masa pandemi Covid-19 tergolong positif.
Penyebab dari hasil belajar mata kuliah IAD yang positif dapat dipicu oleh beberapa faktor. Pertama, topik sains pernah dipelajari di mata kuliah Pendidikan Sains SD. Mata kuliah ini memfasilitasi mahasiswa untuk menguasai konsep sains dan dipelajari di semester 2. Mata kuliah IAD diprogramkan pada semester 5 . Topik-topik yang mahasiswa pelajari di mata kuliah IAD pernah mereka pelajari pada mata kuliah pendidikan sains, kecuali beberapa topik tertentu seperti topik "Alam Pikiran Manusia" dan "Sains dan Perkembangan Teknologi". Konsep sains yang mereka dapatkan pada mata kuliah Pendidikan Sains menjadi pengetahuan awal bagi mahasiswa untuk mempermudah meraka menyerap konsep sains ketika belajar IAD. Seperti diketahui bahwa kemampuan awal penting dalam meningkatkan hasil belajar mahasiswa (Prayitno et al., 2015). Mata kuliah Pendidikan Sains SD yang pernah mereka tempuh juga melatih keterampilan proses sains yang merupakan kompetensi fundamental untuk menguasai konsep sains, dan berkorelasi positif secara signifikan terhadap hasil belajar sains mahasiswa PGSD (Artayasa et al., 2017).

Faktor kedua, tingkat kompetensi yang rendah. Kompetensi sains yang dibekali untuk mahasiswa disesuaikan dengan kompetensi yang dibutuhkan pada mata pelajaran sains SD. Berdasarkan Peraturan Menteri Pendidikan dan Kebudayaan Nomor 37 Tahun 2018, tingkatan paling tinggi proses kognitif dari kompetensi dasar aspek pengetahuan sains di SD hanya sampai C4. Proporsinya kecil, hanya $24 \%$. Proporsi sisanya yaitu sebesar $76 \%$ berada pada C3 ke bawah dengan dipredominasi oleh C2 sebesar $40 \%$ dari seluruh kompetensi dasar yang ada di kelas IV, V, dan VI. Jika mengacu pada Jufri (2013) maka proporsi dari Lower Order Thinking Skilss (LOTS) jauh lebih besar dari proporsi Higer Order Thinking Skills (HOTS). Kompetensi tersebut tentunya relatif mudah bagi mahasiswa yang pernah mendapat berbagai kompetensi, baik produk maupun proses sains, dari SD sampai dengan SMA. Selama perkuliahan pun mereka sudah terbiasa menyelesaikan tugas-tugas yang menuntut kompetensi dengan proses kognitif yang lebih tinggi. Mahasiswa juga relatif lebih mandiri secara psikologi.

Faktor ketiga, kemandirian belajar mahasiswa yang bagus. Hal ini mengacu pada hasil penelitian dari (Nursaptini et al., 2020). Salah satu aspek positif dari adanya perubahan pembelajaran tatap muka menjadi pembelajaran 
daring dimasa pandemi Covid-19 ini adalah terlatihnya kemandirian belajar mahasiswa. Kemandirian belajar sendiri berperan penting terhadap hasil belajar mahasiswa (Atmojo et al., 2020). Di Prodi PGSD FKIP Universitas Mataram, mata kuliah IAD yang mahasiswa programkan di semester gasal Tahun Akademik 2020/2021 merupakan semester kedua diterapkannya pembelajaran daring akibat pandemi Covid-19. Rentang waktu tersebut telah cukup melatih mereka untuk belajar secara mandiri. Hal ini juga didukung dengan pemberian kuota belajar oleh pihak universitas sehingga ketersediaan kuota yang menjadi kendala pembelajaran daring (Indrawati, 2020; Legowo, 2020; Nainggolan et al., 2020) tidak berlaku bagi mereka. Platform pembelajaran daring yaitu SPADA Unram juga dapat di akses selama 24 jam nonstop. Hal ini memberikan kesempatan kepada mahasiswa untuk lebih leluasa belajar di luar jadwal mata kuliah IAD.

Faktor keempat, fasilitas pembelajaran daring yang diberikan sesuai dengan karakteristik mahasiswa dan topik sains pada mata kuliah IAD. Fasilitas pembelajaran yang diberikan kepada mahasiswa pada mata kuliah IAD mencakup SPADA Unram dan model pembelajaran konvensional namun dilakukan secara daring melalui platform Zoom dan Google Meet. Di SPADA Unram mahasiswa dapat mengakses bahan dan media pembelajaran, forum diskusi virtual, dan wadah submit tugas-tugas perkuliahan. Pelaksanaan quiz, UTS dan UAS juga dilaksanakan dengan memanfaatkan SPADA Unram. Model konvensional yang dilakukan secara virtual adalah pembelajaran yang berpusat pada dosen dengan menayangkan power point, dan mahasiswa secara bergiliran melakukan presentasi makalahnya. Pada kedua model konvensional terdapat metode tanya jawab. Pada beberapa topik mahasiswa belajar secara luring dengan memanfaatkan lingkungan sekitarnya sebagai sumber belajar. Variasi pembelajaran tersebut terbukti membuat hasil belajar mereka berkategori baik. Capaian ini perlu dipertahankan dan ditingkatkan melalui implementasi pembelajaran yang dapat mengoptimalkan potensi mahasiswa.

\section{KESIMPULAN}

Berdasarkan hasil penelitian dapat disimpulkan bahwa hasil belajar sains mahasiswa pada mata kuliah IAD dimasa pandemi berada pada kategori baik. Terdapat $34.02 \%$ mahasiswa mendapat hasil belajar dengan kategori sangat baik, dan proporsi tertinggi adalah hasil belajar dengan kategori baik yaitu sebesar 59.79\%. Walaupun demikian, masih terdapat sekitar $2.06 \%$ mahasiswa dengan hasil belajar berkategori sangat kurang. Fakta ini mengindikasikan bahwa perbaikan kualitas pembelajaran dimasa pandemi Covid-19 ini merupakan kebutuhan.

\section{UCAPAN TERIMA KASIH}

Terima kasih penulis sampaikan kepada semua pihak yang telah membantu sehingga terselesaikannya tulisan ini.

\section{REFERENSI}

Artayasa, I. P., Susilo, H., Lestari, U., \& Indriwati, S. E. (2017). Profil keterampilan proses sains dan hubungannya dengan hasil belajar sains mahasiswa Pendidikan Guru Sekolah Dasar. In T. P. T. P. dan P. D. U. N. Malang (Ed.), Seminar Nasional Teknologi Pembelajaran dan Pendidikan Dasar (pp. 706-714). Pascasarjana Teknologi Pembelajaran dan Pendidikan Dasar Universitas Negeri Malang. http://pasca.um.ac.id/conferences/index.p $\underline{\mathrm{hp} / \text { sntepnpdas/article/view/933 }}$

Atmojo, S. E., Muhtarom, T., \& Lukitoaji, B. D. (2020). The level of self-regulated learning and self-awareness in science learning in the Covid-19 pandemic era. Jurnal Pendidikan IPA Indonesia, 9(4), 512-520. https://doi.org/10.15294/jpii.v9i4.25544

Fanani, Q., \& Jainurakhma, J. (2020). Kemampuan penyesuaian diri mahasiswa terhadap pembelajaran daring di tengah pandemi Covid-19. Jurnal KomtekInfo, 7(4), 285-292. https://doi.org/10.35134/komtekinfo.v7i4

Indrawati, B. (2020). Tantangan dan peluang Pendidikan Tinggi dalam masa pandemi Covid-19. Jurnal Kajian Ilmiah, 1(1), 3948.

Jufri, A. W. (2013). Belajar dan Pembelajaran Sains. Bandung: Pustaka Reka Cipta. 
Legowo, Y. A. S. (2020). Kesiapan dan kendala pembelajaran berbasis projek melalui media daring pada mahasiswa Universitas Darul Ulum Islamic Centre Sudirman Guppi. Jurnal Wawasan Pengembangan Pendidikan, 08(02), 62-68.

Nainggolan, J., Pardede, S., \& Butar-butar, I. (2020). Survei kendala Dosen Fakultas Keguruan dan Ilmu Pendidikan Universitas HKBP Nommensen dalam pelaksanaan perkuliahan online. Jurnal Suluh Pendidikan, 8(2), 1-8.

Nursaptini, Syazali, M., Sobri, M., Sutisna, D., \& Widodo, A. (2020). Profil kemandirian belajar mahasiswa dan analisis faktor yang mempengaruhinya: Komunikasi orang tua dan kepercayaan diri. Jurnal Pendidikan Edutama, 7(1), 85-94.

Prayitno, B. A., Corebima, D., Susilo, H., Zubaidah, S., \& Ramli, M. (2015). Closing the science process skills GAP between students with high and low level academic achievement. Journal of Baltic Science Education, 16(2), 266-277.

Rahmatih, A. N., \& Fauzi, A. (2020). Persepsi mahasiswa calon guru sekolah dasar dalam menanggapi perkuliahan secara daring selama masa Covid-19. MODELING: Jurnal Program Studi PGMI, 7(2), 143153.

Sutriyani, W. (2020). Studi pengaruh daring learning terhadap minat dan hasil belajar matematika mahasiswa PGSD era pandemi
Covid-19. Jurnal Pendidikan Dasar, 2(1), 155-165.

Tim Penyusun. (2019). Pedoman Akademik Universitas Mataram. Mataram: Mataram University Press.

Trisniawati, Rhosyida, N., \& Muanifah, M. T. (2020). Eksplorasi hasil belajar mahasiswa melalui penggunaan kuis dan tugas pada E-learning Edmodo di era pandemi Covid19. SCIENCE TECH: Jurnal Ilmu Pengetahuan Dan Teknologi, 6286(2), 3947.

Widiyono, A. (2020). Efektifitas Perkuliahan Daring (Online) pada Mahasiswa PGSD di Saat Pandemi Covid 19 Aan Widiyono. Jurnal Pendidikan, 8(2), 169-177.

Widodo, A., Nursaptini, N., Novitasari, S., Sutisna, D., \& Umar, U. (2020). From face-to-face learning to web base learning: How are student readiness? Premiere Educandum: Jurnal Pendidikan Dasar Dan Pembelajaran, 10(2), 149-160. https://doi.org/10.25273/pe.v10i2.6801

Zamista, A. A., Rahmi, H., Sellyana, A., \& Desriyati, W. (2020). Persepsi mahasiswa terhadap pembelajaran dalam jaringan untuk mata kuliah kalkulus. Jurnal THEOREMS (The Original Research of Mathematics), 5(1), 41-48. http://jurnal.unma.ac.id/index.php/th 